\title{
An empirical survey on biobanking of human genetic material and data in six EU countries
}

\author{
Isabelle Hirtzlin ${ }^{1}$, Christine Dubreuil ${ }^{2}$, Nathalie Préaubert ${ }^{3}$, Jenny Duchier ${ }^{2}$, Brigitte \\ Jansen $^{4}$, Jürgen Simon ${ }^{4}$, Paula Lobato de Faria ${ }^{5}$, Anna Perez-Lezaun ${ }^{6}$, Bert Visser ${ }^{7}$, \\ Garrath D Williams ${ }^{8}$ and Anne Cambon-Thomsen*,2 on behalf of the EUROGENBANK \\ consortium**
}

\begin{abstract}
${ }^{1}$ Panthéon-Sorbonne University, Paris; ${ }^{2}$ Inserm U 558, Toulouse, France; ${ }^{3}$ ANAES, Paris, France; ${ }^{4}$ Europaeische Akademie fuer Umwelt und Wirtschaft, Lueneburg, Germany; ${ }^{5}$ Universidade Nova de Lisboa, Escola Nacional de Saude Publica, Lisboa, Portugal; ${ }^{6}$ Unitat de Biologia Evolutiva, Departament de Ciències Experimentals i de la Salut, Universitat Pompeu Fabra, Barcelona, Spain; ${ }^{7}$ Bert Visser, Centre for Genetic Resources, Wageningen, The Netherlands; ${ }^{8}$ Center for Professional Ethics, University of Central Lancashire, Preston, UK
\end{abstract}

Biobanks correspond to different situations: research and technological development, medical diagnosis or therapeutic activities. Their status is not clearly defined. We aimed to investigate human biobanking in Europe, particularly in relation to organisational, economic and ethical issues in various national contexts. Data from a survey in six EU countries (France, Germany, the Netherlands, Portugal, Spain and the UK) were collected as part of a European Research Project examining human and non-human biobanking (EUROGENBANK, coordinated by Professor JC Galloux). A total of 147 institutions concerned with biobanking of human samples and data were investigated by questionnaires and interviews. Most institutions surveyed belong to the public or private non-profit-making sectors, which have a key role in biobanking. This activity is increasing in all countries because few samples are discarded and genetic research is proliferating. Collections vary in size, many being small and only a few very large. Their purpose is often research, or research and healthcare, mostly in the context of disease studies. A specific budget is very rarely allocated to biobanking and costs are not often evaluated. Samples are usually provided free of charge and gifts and exchanges are the common rule. Good practice guidelines are generally followed and quality controls are performed but quality procedures are not always clearly explained. Associated data are usually computerised (identified or identifiable samples). Biobankers generally favour centralisation of data rather than of samples. Legal and ethical harmonisation within Europe is considered likely to facilitate international collaboration. We propose a series of recommendations and suggestions arising from the EUROGENBANK project.

European Journal of Humans Genetics (2003) 11, 475-488. doi:10.1038/sj.ejhg.5201007

Keywords: human biobanking; genetic collection management; Europe; empirical survey; ethics; economics

${ }^{*}$ Correspondence: Dr A Cambon-Thomsen, Inserm U 558: Epidémiologie et analyses en santé publique: risques, maladies chroniques et handicaps, Faculté de Médecine, 37 allées Jules Guesde, F-31073 Toulouse Cedex, France. Tel: +33 (0)5 611459 59; Fax: +33 (0)5 622642 40;

E-mail: cambon@cict.fr

Received 9 September 2002; revised 4 March 2003; accepted 11 March 2003

**EUROGENBANK consortium Coordinator: JC Galloux, DANTE-Université de Versailles, France. BIOTECH E U Contract: NBIO4-CT98-0570 (DG12-SSMI). Participants: Finland: University of Helsinki (A Sajantila). France: Inserm U 558 Toulouse (A. Cambon-Thomsen), Inserm U 537 Bicêtre (I Hirtzlin), BRG-Paris (A Sontot) \& Inra-Grenoble (M Trommetter). Germany: ZADI - Bonn (F Begemann) \& University of Lünenburg (J Simon). Italy: Università di Siena (C M Mazzoni) \& Università di Torino (A Piazza). Portugal: Universidade Nova de Lisboa (Paula Lobato de Faria) \& INIA - Lisboa/EAN-Oeiras: (Eliseu Bettencourt). Spain: Universitat Pompeu Fabra - Barcelona (J Bertranpetit). Sweden: Nordic Gene Bank - Alnarp (E Thörn). The Netherlands: CPRO - DLO - Wageningen (B Visser). United Kingdom: University of Central Lancashire (R Chadwick) 


\section{Introduction}

Human biological samples in biobanks are stored in a variety of situations. In the clinical domain, hospitals hold large collections primarily aimed at diagnosis and clinical or therapeutic follow-up. Biobanking is also an integral part of forensic medicine and sciences and is routine in the judicial context. ${ }^{1-4}$ Population-based collections have long existed in genetic anthropology and study of the history of world populations but they were usually academic and of modest size. ${ }^{5-7}$ Some larger but rare epidemiological studies have led to the collection of large numbers of population samples. ${ }^{8,9}$ Genetic epidemiologists have stressed that population frequencies of polymorphisms involved in disease are an important parameter in genetic analysis. ${ }^{10}$ However, it was difficult both to acquire relevant large populations and to obtain funding for results that appeared to be of theoretical and not of economic value. Several factors now converge to question practices in biobanking and to motivate the development of large population-based collections. Even small volume samples can now be used for genetic tests years later even if originally obtained for another purpose, more and more polymorphic markers are rapidly becoming available, molecular automated techniques and bioinformatic tools lend themselves to mass screening and databases. ${ }^{11}$ Polymorphisms related to biological functions may play a role in the onset of common diseases and in individual responses to treatment ${ }^{12}$ or they may also give clues for the development of new therapeutic molecules. They are now therefore of primary importance not only to academic or medical geneticists but also to pharmaceutical companies and the biotechnology industry, and they are becoming a major economic issue. The present tendency is to build up large population collections, as has been attempted in Europe in Estonia, Iceland, Latvia, Sardinia, Sweden and the UK. ${ }^{13-15}$ Private funds, sometimes in combination with public funding, support collections that become part of the national resources. The attention of the general public is focused on such large-scale banks. ${ }^{16}$ An understanding of the history of biobanking, the present general context and usual practices is necessary to identify the organisational and ethical issues raised by such new large collections, in the framework of existing activities and more traditional modes of organisation. Large population-based collections are in fact only a part of the picture. Concerns arising from DNA biobanking focused at first on techniques and organisation. ${ }^{17-20}$ Then ethical issues and principles came to the fore, together with regulatory and legal approaches in different contexts and countries. An abundant literature was produced, especially in the United States and Canada and in the fields of forensic and medical diagnosis. $^{21-31}$ More recently, implementation of such principles in daily practice in different professional contexts gave rise to policy papers taking into account not only ethics but also quality and economic issues and necessarily rooted in practice analysis. ${ }^{6,32-37}$ A recent proposal for an EU directive for setting standards of quality and safety for the donation, procurement, testing, processing, storage and distribution of human tissues and cells indicates the importance of this question at European level. ${ }^{38}$ Little information on economic aspects is however available. ${ }^{39}$ An EU funded research project from 1999 to 2001 thus investigated the present status of biobanking activities, in the context of genetics, in several European countries. The EUROGENBANK project, part of the BIOTECH programme implemented under the European Commission 4th Framework Programme on research and technological development, examined the issue of banking genetic material and data in Europe from different points of view: scientific, organisational, economic, legal and ethical. This project examined not only the human field but also microorganism, plant and animal domains. We report here the methodology and main results of our empirical survey of human biobanking in six countries: France, Germany, the Netherlands, Portugal, Spain and the United Kingdom (UK). We aimed to compare the general organisation and main trends including economic parameters, to distinguish the various types of biobanks as observed in the field, to assess organisational and ethical issues as seen by the professionals involved and to draft recommendations for the organisation of biobanking at EU level. In addition to the methodology of the survey, this report concentrates on the following points, as seen by the professionals involved, through their answers to a questionnaire and analysis of their interviews: the type of institution undertaking biobanking, the type and quantity of biological materials preserved, the place of biobanking in the general activities of the institutions, the cost and budget of this activity, ownership, legal and ethical issues, taking into account exchange policies. The results of our survey enable a discussion on the strategic position of biobanking activities in various contexts and on the evolution of the sector, especially with the appearance of professional biobankers. Finally, we propose a series of recommendations generated by this survey.

\section{Material and methods Criteria of biobanks surveyed}

The categories of collections investigated fulfilled the following criteria: systematically organised, accessible open to third persons, established for the purpose of studying and/or using and/or preserving genetic information; in addition, this purpose had to be the primary goal of the collection; the collection should consist of living organisms and/or DNA and/or sources of DNA or DNAbased information. We excluded biological samples gathered exclusively for therapy (transplants, blood, gametes and embryos), those exclusively preserved for diagnosis (except genetic diagnosis and molecular diagnosis), and 
lists or catalogues of reagents (probes and oligonucleotides).

An overview of the general organisation and framework of biobanking in each country was obtained from publicly available sources, official administrative information, statistics from directories, reports, web sites and previous surveys if any. This enabled us to select possible targets for the empirical survey.

Targets were chosen using information gathered during the overview (the Netherlands and Portugal and the UK), completed by additional procedures in three countries: preselection through a short questionnaire in one case (France), large-scale mailing (Germany) or selection through personal or phone contacts (Spain). The following criteria were applied:

(1) Institutions of all types or status (public, private, centre for cancer or specific diseases, associations, consultative boards, animal laboratories, etc) had to be represented in the targeted sample.

(2) As the size of collections is a key parameter, a large collection as a model of gene banking and one or several smaller collections were targeted in order to compare their mode of operation.

(3) The country was covered geographically as much as possible.

(4) Lastly, diverse pathologies were studied in order to cover numerous medical specialties and networks.

\section{Questionnaire and interviews}

A questionnaire was sent together with a letter presenting the project. This mailing was preceded in certain cases by a telephone contact. Questionnaires were completed directly by the respondents; a phone or personal interview was obtained systematically in one country (France) or as a complementary means of acquiring information in other cases. The 60 questions of the questionnaire were divided into 10 sections (Table 1). Additional documents or sources of information were sometimes provided. Data were gathered in 1999 and 2000.

\section{Data management and analysis}

The data from the various sections of the questionnaire were coded in 200 variables for quantitative analysis and interviews were summarised. The content of other documents was analysed and general and specific characteristics and trends were derived for each country.

\section{Results \\ Institutions analysed in the survey sample}

A total of 147 institutions doing biobanking in six countries were closely investigated: 67 in France, 42 in Spain, 12 in the UK, 11 in Portugal, 10 in Germany, five in the Netherlands (Table 2). The response rate varied between countries, although the questionnaire and general methodology were the same. This is partly due to

Table 1 Information obtained by questionnaire and/or interviews of persons involved in biobanking in the targeted institutions in six EU countries

1. Information on the institution and the position of biobanking activities (legal and administrative status, type and size of institution general organisation, number of collections, ownership of collections)

2. Description of collections (number of samples, type of biological material, source, criteria of inclusion in collections, purposes, percentage of biobanking activity in the institution, originality of collections)

3. Mode of acquisition of collections (regulatory framework (legal, administrative, ethical), methods used to obtain knowledge of this framework, existence of specific insurance for collections, means of sample procurement, of recruiting donors, type of written information provided to potential donors, use of a consent form, type of personal information included, existence of good practice guidelines)

4. Work done on samples and its cost (type of handling, quality control, security and biological protection measures, identified budget or not, source of budget, elements included in the costs reported)

5. Characteristics of sample storage (length of storage, criteria for discarding samples, cost of storage per type of sample, duplication of storage in another bank)

6. Exchanges and distribution (flow rate, framework of exchanges, rules and range of access, conditions for withdrawal, existence of formal agreement documents, expenses charged)

7. Dissemination of information (methods of information distribution, confidentiality or intellectual property rules)

8. Computerisation (type of database or data management system used, proportion and type of data computerised, degree of possible identification of individuals through samples or data)

9. Difficulties encountered (regulations, acquisition, management, exchanges of samples)

10. Present and future organisation (existing or foreseeable agreements, organisation at international level, cooperation networks, sector evolution foreseen, position on agreements, ethical and regulatory framework at European level, position on centralised organisation of samples, of data, possible involvement of the institution in centralisation activities, personal opinions and suggestions)

The above 10 sections were presented as a questionnaire with 60 closed or open-ended questions, which could be filled in by one or several persons in a given institution (autoadministration) or filled in during a personal interview or by telephone. Additional information provided by some institutions was analysed in order to complement or illustrate certain answers: models of consent forms, guidelines or good practise documents, procedure form for withdrawal, price catalogue, contract or cooperative agreement, Internet web site, activity report. 
Table 2 Sampling of institutions involved in human genetic biobanking performed for EUROGENBANK in six EU countries

\begin{tabular}{|c|c|c|c|c|c|c|}
\hline & France & Germany & Netherlands & Portugal & Spain & United Kingdom \\
\hline $\begin{array}{l}\text { Institutions } \\
\text { contacted }\end{array}$ & $\begin{array}{l}437 \text { (158 } \\
\text { responded, } 115 \\
\text { agreed to } \\
\text { participate) }\end{array}$ & $\begin{array}{l}38 \text { (of } 650 \text { first } \\
\text { contacts by letter) }\end{array}$ & 19 & 24 & 44 & 45 \\
\hline $\begin{array}{l}\text { Institutions } \\
\text { interviewed or } \\
\text { institutions } \\
\text { completing the } \\
\text { questionnaire }\end{array}$ & $\begin{array}{l}67 \text { (majority in } \\
\text { Paris and } \\
\text { Toulouse) }\end{array}$ & 10 & 5 & 11 & $\begin{array}{l}42 \text { (mostly in } \\
\text { larger cities) }\end{array}$ & 12 \\
\hline $\begin{array}{l}\text { Status of } \\
\text { institutions } \\
\text { interviewed }\end{array}$ & $\begin{array}{l}58 \text { public and } \\
\text { private not-for- } \\
\text { profit-nine private } \\
\text { for-profit }\end{array}$ & $\begin{array}{l}10 \text { public and private } \\
\text { not-for-profit }\end{array}$ & Five public & $\begin{array}{l}11 \text { public and } \\
\text { private not-for- } \\
\text { profit }\end{array}$ & $\begin{array}{l}41 \text { public and } \\
\text { private not-for } \\
\text { profit- } 1 \text { half private } \\
\text { and half public }\end{array}$ & $\begin{array}{l}12 \text { public and } \\
\text { private not-for- } \\
\text { profit }\end{array}$ \\
\hline
\end{tabular}

Table 3 Institutions storing human samples in Europe and their representation in the EUROGENBANK survey of six EU countries

\begin{tabular}{|c|c|c|c|c|c|c|}
\hline Status & France & Germany & Netherlands & Portugal & Spain & United Kingdom \\
\hline $\begin{array}{l}\text { Laboratories within hospitals or health institutes (public } \\
\text { or private not-for-profit) }\end{array}$ & 35 & 8 & 3 & 1 & 32 & 7 \\
\hline Research and university laboratories & 7 & 2 & 2 & 9 & 6 & 2 \\
\hline Firms (biotech or pharmaceutical companies) & 9 & 0 & 0 & 0 & 0 & 0 \\
\hline Centres for study and preservation of eggs and sperm & 5 & 0 & 0 & 0 & 0 & 0 \\
\hline Blood banks & 2 & 0 & 0 & 0 & 0 & 1 \\
\hline Patient associations & 3 & 0 & 0 & 0 & 0 & 0 \\
\hline Forensic institutions & 3 & 0 & 0 & 1 & 3 & 2 \\
\hline Others & 3 & 0 & 0 & 0 & 1 & $\overline{0}$ \\
\hline Total number & 67 & 10 & 5 & 11 & 42 & 12 \\
\hline
\end{tabular}

heterogeneity in practical organisation of the survey in each country. Personal knowledge of key actors in the sector was important for obtaining good coverage of all types of biobanks and well-documented answers. However, the main aim was to cover the existing diversity in biobanking and some representative examples in the main sectors, rather than to obtain exhaustive quantitative information. Table 3 presents the type of institutions involved in biobanking as identified in the six countries through the general overview as well as their representation in the sample more closely investigated in each country. Genetic material banking involves all kinds of research or healthcare organisations. Potential sources of DNA samples are numerous, including hospitals, pharmaceutical groups, biotechnology companies, patient associations, forensic services and research laboratories. Hospitals obviously have a key role in establishing collections, because biological samples are mainly collected in healthcare services directly from patients. Attention was focused on hospital services that were the most represented. Portugal seems to be an exception.

\section{Characteristics of banked genetic material}

A variety of genetic materials and data are banked (Table 4). The various types of biological samples require different preservation conditions (mainly freezers $\left(-80^{\circ} \mathrm{C}\right)$ for DNA, blood, tissues, serum and plasma, or liquid nitrogen for cells and cell lines) and correspond to different fields of activity. The attached databases are also diverse in their content. General categories documented are family samples or unrelated individuals with various degrees of personal identification as described elsewhere ${ }^{24,40}$ (identified, identifiable, anonymized or anonymous) with different types of information attached to the sample (personal, medical) a priori or a posteriori (e.g. resulting from a lab test). Information may also be unattached to individual samples but may relate to a collection as such or to a group of people (frequencies of markers in a population). 
Table 4 Amount and category of biological samples banked in the various types of institutions investigated in six EU countries

\begin{tabular}{|c|c|c|c|c|c|c|c|c|c|}
\hline & \multicolumn{3}{|l|}{$D N A$} & \multicolumn{3}{|l|}{ Blood } & \multicolumn{3}{|l|}{ Tissues } \\
\hline & $\begin{array}{l}\mathrm{N} \\
\text { Institutions }\end{array}$ & $\begin{array}{l}\text { Total N } \\
\text { samples }\end{array}$ & $\begin{array}{l}\text { Mean } \mathrm{N} \\
\text { samples } \\
\text { Most cited } \\
\text { range }\end{array}$ & $\begin{array}{l}\mathrm{N} \\
\text { Institutions }\end{array}$ & $\begin{array}{l}\text { Total N } \\
\text { samples }\end{array}$ & $\begin{array}{l}\text { Mean } \mathrm{N} \\
\text { samples } \\
\text { Most cited } \\
\text { range }\end{array}$ & $\begin{array}{l}\mathrm{N} \\
\text { Institutions }\end{array}$ & $\begin{array}{l}\text { Total N } \\
\text { samples }\end{array}$ & $\begin{array}{l}\text { Mean N } \\
\text { samples } \\
\text { Most cited } \\
\text { range }\end{array}$ \\
\hline France & 42 & 126113 & $\begin{array}{l}4204 \\
101-1000 \text { and } \\
1001-5000\end{array}$ & 19 & 12768 & $\begin{array}{l}1596 \\
4-1000 \text { and } \\
1001-100000\end{array}$ & 25 & 18355 & $\begin{array}{l}1311 \\
25-1000\end{array}$ \\
\hline Germany & ND & & $50-8000$ & ND & & $40-50$ & ND & ND & $30-300$ \\
\hline Netherlands & 5 & $>100000$ & $\begin{array}{l}10001-20000 \\
>50000\end{array}$ & 2 & $>60000$ & $>50000$ & ND & ND & ND \\
\hline Portugal & 10 & 11468 & $\begin{array}{l}1274 \\
101-500 \text { and } \\
501-1500\end{array}$ & 5 & 1740 & $\begin{array}{l}580 \\
500-1000\end{array}$ & 5 & 7659 & $\begin{array}{l}1914 \\
101-500\end{array}$ \\
\hline Spain & 10 & 16378 & $\begin{array}{l}1638 \\
101-1000 \text { and } \\
1001-5000\end{array}$ & 34 & 2956300 & $\begin{array}{l}86950 \\
35000-700000\end{array}$ & 1 & 50 & $\begin{array}{l}50 \\
20-100\end{array}$ \\
\hline UK & 7 & 43700 & $\begin{array}{l}7283 \\
1001-5000 \\
7001-35000\end{array}$ & 2 & 11450 & $\begin{array}{l}5725 \\
201-1000 \\
4501-15000\end{array}$ & 3 & 4859 & $\begin{array}{l}1620 \\
25-1000 \text { and } \\
1001-9000\end{array}$ \\
\hline \multirow[t]{3}{*}{$\begin{array}{l}\text { Total/major } \\
\text { trend }\end{array}$} & $>95$ & $>300000$ & $\begin{array}{l}\text { Median: } \sim 1000 \\
\text { (for small banks) }\end{array}$ & $>62$ & $>3042258$ & $<1000$ or $>30000$ & $>35$ & $>30923$ & $\begin{array}{l}<1000 \text { or } \\
1000-10000\end{array}$ \\
\hline & \multicolumn{3}{|l|}{ Cells } & \multicolumn{3}{|l|}{ Cell lines } & \multicolumn{3}{|c|}{ Serum or Plasma } \\
\hline & $\begin{array}{l}N \\
\text { Institutions }\end{array}$ & $\begin{array}{l}\text { Total N } \\
\text { samples }\end{array}$ & $\begin{array}{l}\text { Mean N } \\
\text { samples } \\
\text { Most cited } \\
\text { range }\end{array}$ & $\begin{array}{l}N \\
\text { Institutions }\end{array}$ & $\begin{array}{l}\text { Total N } \\
\text { samples }\end{array}$ & $\begin{array}{l}\text { Mean N } \\
\text { samples } \\
\text { Most cited } \\
\text { range }\end{array}$ & $\begin{array}{l}N \\
\text { Institutions }\end{array}$ & $\begin{array}{l}\text { Total N } \\
\text { samples }\end{array}$ & $\begin{array}{l}\text { Mean N } \\
\text { samples } \\
\text { Most cited } \\
\text { range }\end{array}$ \\
\hline France & 29 & 46610 & $\begin{array}{l}2453 \\
35-1000\end{array}$ & 31 & 69884 & $\begin{array}{l}3038 \\
7-700\end{array}$ & 27 & 698779 & $\begin{array}{l}38821 \\
4-1000 \text { and } \\
1001-100000\end{array}$ \\
\hline Germany & $\begin{array}{l}\text { ND } \\
\text { (several) }\end{array}$ & $>600$ & $99-600$ & $\begin{array}{l}\text { ND } \\
\text { (several) }\end{array}$ & $>200$ & $10-200$ & ND & $>1000$ & ND \\
\hline Netherlands & ND & ND & ND & $\begin{array}{l}\text { ND } \\
\text { (several) }\end{array}$ & $>1000$ & ND & ND & ND & ND \\
\hline Portugal & 5 & $>30$ & $\begin{array}{l}15 \\
<50\end{array}$ & 4 & 28 & $\begin{array}{l}14 \\
<50\end{array}$ & 2 & $300-500$ & $\begin{array}{l}\sim 300 \\
300-500\end{array}$ \\
\hline Spain & 2 & 220 & $\begin{array}{l}110 \\
20-100 \\
101-1000\end{array}$ & 5 & 2320 & $\begin{array}{l}464 \\
20-100 \text { and } \\
101-5000\end{array}$ & 3 & 8400 & $\begin{array}{l}2800 \\
101-1000 \text { and } \\
7000-35000\end{array}$ \\
\hline UK & 2 & 500 & $\begin{array}{l}500 \\
35-1000\end{array}$ & 0 & & & 0 & & \\
\hline $\begin{array}{l}\text { Total/major } \\
\text { trend }\end{array}$ & $>38$ & $>47960$ & $<1000$ & 40 & 73342 & $\begin{array}{l}<100 \\
100-1000\end{array}$ & 32 & >708679 & $\begin{array}{l}10-1000 \\
5000-100000\end{array}$ \\
\hline
\end{tabular}

ND: Not documented. Note: Not all institutions gave a precise number of samples; some only gave a range. The mean number of samples is calculated only relative to the institutions giving precise quantitative information, whereas the range takes into account the totality of answers.

Completely anonymous samples are the exception and in general coded samples are used for research applications and identified samples for clinical purposes.

The type of samples and their approximate numbers in the banks studied are given in Table 4. Numbers are underestimated and are indicative, as only some institutions gave precise answers. DNA was found to be the most commonly stored material, both because our survey was carried out in the context of genetics and because DNA is easy to preserve when extracted in small volumes, at low cost (refrigerators or $-20^{\circ} \mathrm{C}$ freezers). Other nucleic acids or human genetic constructions in microorganisms for genomic studies are found especially in research banks and in large banks providing services such as the Resource Centre of the German Human Genome Project (RZPD) in Germany. Blood (especially in Spain) and tissues are the most common biological materials stored in large quantity. Serum or plasma is preserved for clinical or epidemiological 
purposes. Some other biological materials such as tumours, tissues, nails or hair were reported, especially in Spain. In relation to clinical genetics or pathology services, banks with only one type of biological material (DNA, tissues) are frequent, whereas multiple types of biological material are encountered in research contexts and in institutions where biobanking was reported as a major function. Such institutions often also host samples of non-human species.

Banking of samples is either patient oriented (health institutions), or research and health (university hospitals) or purely research oriented, other reasons being the minority. The frontier between clinical and research uses seems impermeable in certain contexts, especially in the Netherlands, but more flexible in others in the direction 'primary clinical use then research use'. Cell lines and DNA are the materials most commonly exchanged. Most collections are working collections and for several years the general tendency has been towards increased biobanking activity (Table 5) for all types of biological materials. This was especially marked for DNA banking, where more than $80 \%$ of the institutions studied observed an increase in the last 5 years. This was less marked in Portugal. Cell lines were less affected by the increase than other materials. This overall evolution is expected to continue in the coming years. Most research and clinical collections rarely discard samples. When they do so, their reasons are most often lack of space or a technical problem (sample unusable). Thus, the increase in activity is due both to the long-term storage of existing samples and to the addition of new ones. This frequently leads to budgetary concerns in all countries (see below). Only a minority of the institutions we investigated would be able to manage large banks with complex organisation and would be willing to play a role in centralisation.

Although good practice manuals exist and some kind of quality control is carried out in the majority of cases in the six countries, quality control was not systematic and a wide variety of practices were reported. An ISO 9001 certification with duplication of the bank in another country, for example, was reported for an epidemiological collection in the Netherlands, whereas no specific control of procedures were organised in other cases. More attention was paid to quality control in large banks and in private companies.

\section{Position of biobanking within the institutions}

Storage of genetic material is not always obviously related to the main role of the institution and its importance is subject to the evolution of the present situation. Some institutions have felt the need to preserve genetic material for a long time even if it had no direct link with their objectives (for example, hospital departments had col-

Table 5 Evolution of the number of samples stored in the past 5 years

\begin{tabular}{|c|c|c|c|c|c|c|c|c|c|c|c|c|c|c|c|}
\hline & \multicolumn{5}{|c|}{ Evolution of number of DNA samples } & \multicolumn{5}{|c|}{$\begin{array}{l}\text { Evolution of number } \\
\text { of blood samples }\end{array}$} & \multicolumn{5}{|c|}{ Evolution of number of tissues } \\
\hline & $\begin{array}{l}\mathrm{N} \\
\text { answers }\end{array}$ & Increase & Stable & Decrease & e Unknown & $\begin{array}{l}\mathrm{N} \\
\text { answers }\end{array}$ & Increase & Stable & Decrease & Unknown & $\begin{array}{l}\mathrm{N} \\
\text { answers }\end{array}$ & Increase & Stable & Decrease & Unknown \\
\hline France & 42 & 31 & $2 / 9$ & 0 & 9 & 20 & 8 & 3 & 1 & 8 & 25 & 14 & 4 & 0 & 7 \\
\hline Germany & Imprecise & Yes & & & & Imprecise & Yes & & & & Imprecise & Yes & & Yes & \\
\hline Netherlands & 10 & 10 & 0 & 0 & 0 & ND & & & & & Imprecise & yes & & & \\
\hline UK & 7 & 7 & 0 & 0 & 0 & 3 & 1 & 2 & 0 & 0 & 3 & 3 & 0 & 0 & 0 \\
\hline \multirow[t]{2}{*}{$\begin{array}{l}\text { Total/major } \\
\text { trend }\end{array}$} & $>80$ & $>64(>80 \%)$ & & & & $>63$ & $\begin{array}{l}>45 \\
(>71 \%)\end{array}$ & & & & $>35$ & $\begin{array}{l}>22 \\
(>63 \%)\end{array}$ & & & \\
\hline & \multicolumn{5}{|c|}{ Evolution of number of cellular samples } & \multicolumn{5}{|c|}{ Evolution of number of cell lines } & \multicolumn{5}{|c|}{ Evolution of number of serum or plasma samples } \\
\hline UK & 2 & 2 & 0 & 0 & 0 & None & & & & & None & & & & \\
\hline Netherlands & Imprecise & Yes & & & & ND & & & & & Imprecise & Yes & & & \\
\hline $\begin{array}{l}\text { Portugal } \\
\text { Germany }\end{array}$ & $\begin{array}{l}5 \\
\text { Imprecise }\end{array}$ & $\begin{array}{l}2 \\
\text { Yes }\end{array}$ & 0 & 0 & 3 & $\begin{array}{l}4 \\
\text { Imprecise }\end{array}$ & $\begin{array}{l}2 \\
\text { Yes }\end{array}$ & 0 & 0 & 2 & $\begin{array}{l}2 \\
\text { Imprecise }\end{array}$ & $\begin{array}{l}1 \\
\text { Yes }\end{array}$ & 0 & $\begin{array}{l}0 \\
\text { Yes }\end{array}$ & 1 \\
\hline $\begin{array}{l}\text { Total/major } \\
\text { trend }\end{array}$ & $>40$ & $>29(>72 \%)$ & & & & $>42$ & $\begin{array}{l}>19 \\
(>45 \%)\end{array}$ & $\begin{array}{l}14 \text { stable } \\
(33 \%)\end{array}$ & & & $>35$ & $\begin{array}{l}>21 \\
(60 \%)\end{array}$ & & & \\
\hline
\end{tabular}

ND: Not documented. 
lected samples for research before being able to diagnose patients' illnesses from these samples). The most ancient collections are more often assigned to healthcare and the more recent ones to research. Collections are established and used by a variety of scientific and medical actors in all disciplines: geneticists, biologists of other specialties (biochemistry, immunology and pathology) and clinical specialists interested in a given disease (rheumatology, neurology and oncology). The Netherlands, France and Germany, for instance, provided long lists of genetic diseases studied. This reflects the fact that genetic investigations (as was true years ago for immunology and molecular biology) were previously carried out mainly by geneticists and only gradually became part of standard investigations in other specialties. Collection-based exchanges are becoming a tool for increasingly diverse scientific uses (Table 6). Classic genetic studies mainly researched trait transmission through family investigation. The present trend is to increase use of samples at population level, pharmacogenomics being a large forthcoming field of study. ${ }^{12,16,41}$ However, this kind of application is far from playing an important part in existing banks.

Dedicated biobanks Some dedicated biobanks already exist and have a major role in sample preservation, even if they follow their own specific objectives. We distinguished two different types:

(1) Institutions which had a historical role of preservation for various purposes and which have extended this role to genetics (blood banks and centres for preservation of eggs and sperm (CECOS in France). There is a specific example of this in France, where due to the contamination of blood samples by the human immunodeficiency virus (HIV), the transfusion sector has been completely reorganised and a specialised national agency created, the Etablissement
Français du Sang (EFS). Procedures are centrally controlled and standardised. Blood centres must keep two samples after each donation. Even if these samples are not used for genetic purposes, blood banks have developed specific know-how for the preservation of blood and derivatives. They provide services to 'customers' (usually public institutions which have to maintain large collections for epidemiological studies). The blood banks do not transform the samples for genetic analysis, so public institutions using the service have to provide their own collections to the blood banks. Moreover, there is a real distinction between the circuit of sample storage as a legal obligation and storage as a service activity. For storage of blood samples, the EFS allocates a dedicated budget which covers the running costs. To respond to the demand of public institutions, the bank charges them through cooperation contracts. The procedure is the same for the CECOS, which have their own activity (preservation of sperm and eggs) and also have research contracts. Blood banks have the advantage of their experience in industrial processing of large numbers of samples and their organisation on a local basis.

(2) Institutions which were created in the context of the human genome project and received specific budgets for this activity. Representative examples are the Centre d'Etude du Polymorphisme Humain (CEPH) and Genethon from the Association against Myopathy in France, and the Resource Centre of the German Human Genome Project (RZPD) in Germany. These centres now have collections that can be used for several purposes and continue to maintain samples or databases. Nevertheless, funds for the genome project are limited in amount and duration, and centres are trying to raise money through research contracts or fees for services, essentially by making use of their know-how and providing a service activity for DNA extraction or cell transformation.

Table 6 Use of collections by country and order of importance

\begin{tabular}{|c|c|c|c|c|c|c|c|}
\hline Purpose & France & Germany & Netherlands & Portugal & Spain & United Kingdom & Total \\
\hline Diagnosis & $46^{\mathrm{a}}$ & yes & yes & 7 & 32 & 5 & $>90$ \\
\hline Familial studies & 32 & yes & yes & 9 & 3 & 6 & $>50$ \\
\hline Polymorphism characterisation & 29 & yes & yes & 4 & 8 & 5 & $>46$ \\
\hline Epidemiological studies & 25 & yes & yes & 6 & 4 & 4 & $>39$ \\
\hline Functional studies & 29 & yes & yes & 3 & 0 & 3 & $>35$ \\
\hline Clinical follow-up & 26 & yes & yes & 4 & 0 & 3 & $>33$ \\
\hline Genetic mapping & 17 & yes & yes & 3 & 2 & 5 & $>27$ \\
\hline $\begin{array}{l}\text { Development of substances of } \\
\text { industrial interest }\end{array}$ & 9 & ND & ND & 1 & 0 & 1 & 11 \\
\hline Drug development & 8 & ND & ND & 1 & 0 & 1 & 10 \\
\hline Pharmacogenomics & 8 & ND & ND & 0 & 0 & 2 & 10 \\
\hline Gene therapy & 8 & ND & ND & 0 & 1 & 0 & 9 \\
\hline Other & 0 & ND & ND & 0 & 0 & 1 & 1 \\
\hline
\end{tabular}

${ }^{a} 46$ for France means that in the questionnaires returned, the use of collections for diagnosis was mentioned 46 times.

ND: not documented by the research team. Yes: indicates that this purpose has been documented in the country but that no quantified evaluation was available. 
It is also important to mention that a large number of institutions do not store genetic material but use it for their activity. Users who are not themselves biobankers appear especially in the private sector and their rules or codes of conduct are unclear. These 'users' legitimate the existence of specific institutions such as dedicated banks.

\section{Costs and resources used for biobanking}

Biobanking does not directly generate profit and must be subsidised In the six countries we studied, samples were most often accessed through scientific collaboration. In the large majority of cases, they were provided free of charge, which means that gift exchanges are common (in some cases the centre receiving the samples may pay extraction expenses). For DNA diagnostics, some countries have established a standard tariff: $500 €$ in the Netherlands, $190 €$ in France, which is applied by all clinical genetic centres in the country. The banking activity is organised in various ways but is usually financed by the global budget of the institution (Table 7). Often, the activity has no dedicated budget and banking activities must be cross-subsidised through other research contracts; this situation was previously described in France. ${ }^{39}$ Sample storage is rarely a fully recognised activity, except in some pharmaceutical groups or biotechnology companies. Even for bigger banks, continuity of funding is not always assured. For those involved, regrouping of the banking activity could enable economies of scale and cut costs. However, it has to be compatible with simplicity of use.

Lastly, in the six countries, at the time of our survey, there was no public policy that covered the financing of DNA banking. There is a risk that academic laboratories may abandon DNA banking because proportionally it takes up too much of their global budget. Funding problems were often mentioned as one of the difficulties affecting sample storage (France, Spain, Germany). In France, some private companies are already managing to find solutions and are studying the development of DNA banking services for other companies or academic laboratories. These private firms will charge for banking, which raises the question of inequality of access for public laboratories that cannot afford such payment. It is too soon to assess the recent initiative of the French Research Ministry concerning the funding of Biological Resource Centres. ${ }^{42}$ However, there is increasing awareness of the economic situation as well as of the ethical issues of banking biological material, ${ }^{43,44}$ especially in a hospital context.

Lack of finance and the interweaving of biobanking among other activities could explain why the funds dedicated to banking were usually claimed to be limited. The surface area of the banks ranged from very small (less than $50 \mathrm{~m}^{2}$ ) to very large (nine banks had a surface area of $150-300 \mathrm{~m}^{2}$ ). Nitrogen containers, one of the most common items of equipment, were few in number, as were freezers $\left(-20\right.$ and $\left.-80^{\circ} \mathrm{C}\right)$. Limited facilities may also be linked with the relatively small number of samples generally encountered in individual banks as described. People involved in the banking activity also form only small teams even in big institutions; banks usually employ less than five technicians and the total number of biologists or physicians working in banking in our survey does not exceed one or two even in large banks.

Gift and exchange relations are the rule Exchanges are rarely formalised. The scientific collaboration giving access to samples usually simply states the scientific purpose for which part or all of a collection will be used. Such collaboration may follow a meeting at a congress, a letter regarding a publication in which the collection is mentioned, more recently communication through the Internet or most often between clinicians or scientists who know each other through their discipline network. When a biobank hosts several collections, the rules governing access may differ according to the collection. Collections belonging to or hosted by large not-for-profit organisations are those with the most clear-cut rules of access.

The mode of sample allocation between banks is not guided by market relations. Considerations by Arrow $^{45}$ concerning blood donations can be extended to biological samples. For this author, in the language of welfare economics, there are 'externalities', benefits and costs transmitted among individuals for which compensation in price terms is not and perhaps cannot be obtained. In the dynamics of scientific production, biological samples are research intermediary products when final products are publications or patents. Even if the research material is a critical resource, the necessity to corroborate results by other teams using the same biological material or to reach a

Table 7 Sources of funding for biobanking activity

\begin{tabular}{|c|c|c|c|c|c|c|c|}
\hline Funding sources (number of banks per country) & France & Germany & Netherlands & Portugal & Spain & United Kingdom & Total \\
\hline Global budget of the institution & 56 & 9 & 5 & 9 & 38 & 5 & 122 \\
\hline Funding by co-operative agreement & 10 & 9 & 0 & 1 & 5 & 1 & 26 \\
\hline Sales & 6 & 0 & 0 & 0 & 0 & 0 & 6 \\
\hline Unanswered & 0 & 0 & 0 & 0 & 0 & 4 & 4 \\
\hline Total (double entries allowed) & 99 & 27 & 5 & 10 & 44 & 13 & 198 \\
\hline
\end{tabular}


critical mass of samples can partly explain the importance of the sample flows between laboratories. Research strategy also consists in keeping samples and data private before the publication of the research. After publication, the question of a given access to samples arises and usually researchers prefer keeping the samples and controlling their use rather than throwing them away. The question of long-term maintenance and management of collections is now emerging.

Differences in prices and costs make comparisons difficult. A number of laboratories had not calculated their full cost and many underlined the difficulties of evaluating it without in-depth analysis of all cost parameters. Level of activity is also heterogeneous and any conclusion as to economies of scale is impossible. However, two results stand out:

(1) The cost of sample storage appears to be relatively small compared to the cost of sample handling before storage, and

(2) DNA isolation should be the most uniform operation but its cost ranges from $2 €$ to $114.3 €$ per sample.

Thus, concerning European organisation, before determining a tariff that could be used as a reference for exchanges between DNA banks, precise analysis of cost and production functions is required. At present, cost studies are lacking in uniformity, probably because the methodology used to calculate cost is not the same. Moreover, some banks are financed through research contracts and exchanges are free of charge between contractors (except for shipping expenses in some cases). This explains why bank managers have only an approximate idea of the cost per sample.

\section{Ownership, legal framework and ethics}

The questions about the ownership of samples, data and collections led to an unexpected variety of answers. In the majority of cases, institutions own the collections they establish and host, but the number of owners can be very large (hundreds) for multiple collections hosted in a large bank. Ownership was also reported to belong to individual researchers (concerning engineered biological material, in Germany for example) or to the persons who had provided the samples (France, Germany). Most often, ownership was not transferred when material was exchanged. Certain confusion exists between ownership and the responsibility for managing samples. Ownership of a collection and control of their own material by individuals who were sampled are also sometimes poorly defined notions. The larger collections have a more stringent framework than small ones. However, throughout the six EU countries, it is probable that the total number of samples held in small loosely structured collections is greater than that in existing large ones. Control of use of the samples and data by the clinician or scientist at the origin of a collection is the general practice for small size collections. Most collections practise restricted access, access being easier for public institutions.

Specific legislation concerning collections was not reported as such in detail by the majority of professionals questioned, even when such a framework exists, as in France; ${ }^{46,47}$ but ethical issues were generally known and those reported were related to information and consent, data confidentiality, exchange and management. Consent forms have gradually come into use, more recently in writing; even if not mandatory by law, internal codes of conduct have been established, as in Spain. Their content is variable and very heterogeneous. The practice of obtaining written consent for banking samples is more frequent in a research than in a clinical health context. However, explicit consent for banking activity as such is a recent issue and not all banks use such a form. Most often, the consent form relates to the primary use envisaged and long-term use is not always mentioned. Likewise, duration of storage is not always specified. The issue of data protection is a generally well-known and sensitive topic in the context of medical data and genetics. The question of secondary use of samples and of further consent is a concern among researchers and clinicians doing research, but no national consensus on adequate solutions was reported in any country. Individual positions were variable. As many of the collections surveyed have existed for more than 10 years and awareness of ethical issues has since considerably increased, the issue remains unresolved for ancient collections. Ethical questions regarding the use in connection with private companies of samples collected in a clinical or research context were generally felt to be highly problematic when such an eventuality had not been foreseen. The disparity of regulatory frameworks in different countries is seen as a complication for banks involved in numerous exchanges and collaborative research. A large proportion of respondents expressed the need for information on legal and ethical guidelines when the rules were perceived as complex (France) or inadequate (Spain) and harmonisation was seen as positive if it did not lead to administrative complications. Perception of the need for a strict framework and awareness of specific ethical issues were greater in large banks undertaking numerous exchanges.

The following ethical issues already analysed in different contexts ${ }^{26,27,30,31,35,47-49}$ were stressed by our respondents:

- How can we protect the rights to autonomy, confidentiality and privacy of persons whose samples and data are in the biobanks, and the rights of researchers?

- How can we ensure the noncommercial use of human biological material and control the development of commercial products directly issuing from the samples?

- How can we provide correct information when we cannot foresee future developments? The complexities 
of informed consent were sometimes found impracticable if too stringent, as suggested in other studies. ${ }^{22,50-54}$

- How can we ensure maximum quality of sample preservation and management, together with uncomplicated access to samples?

- How can we use the samples optimally and openly to further the rapid advance of knowledge, while safeguarding the rights of priority of the researchers who established the collection and if applicable, the interests of the companies involved?

Issues in biobanking were first seen as technical problems by professionals, then as ethical concerns also mainly by professionals. They are now increasingly addressed by regulatory authorities at a political level. This is shown in France by the extended report requested by the General Inspection of Social Affairs and the General Inspection of Research and National Education Administration in 2001 and published in $2002{ }^{43}$ and at a European and international level by the inclusion of this topic in several EU conferences from 2001 to 2003 (Ethics and biomedical research - the process of balancing benefits and risks. 11-12 June 2001, Umeå, Sweden, http:// www.eu2001.se/education/eng/docs/umea_progr_en.asp European Science Foundation Conference on Biobanks in Uppsala, 12-13 September 2002 http://www-conference.slu.se/biobanks/index.htm

EU Conference: Ethics in Research and Science. Situation and Perspectives in the Candidate Countries to the European Union, March 17-19, 2002, Bratislava, Slovak Republic http://www.scienceandsociety.net/cybercafe.htm

Biobanks for Health - Workshop - Voksenåsen hotel, Oslo - 28-31 January 2003. http://www.fhi.no/hvaskjer/ biobanks_workshop.html) and in international meetings. ${ }^{44,55}$ The recent proposal for an EU Directive for setting standards of quality and safety for the donation, procurement, testing, processing, storage and distribution of human tissues and cells takes into account a number of the issues dealt with in our survey. ${ }^{38}$ However, it only relates to healthcare activities and does not include research activities. Thus, it is a good source of information and suggestions but cannot be considered as a regulatory text covering all activities related to biobanking.

\section{Discussion}

\section{Relevance of our sample}

As it was not possible to carry out a detailed survey at the European level within the framework of the EUROGENBANK project, we focused on some banks considered as representative by professionals, and not on exhaustiveness. Almost all institutions interviewed belong to the public sector or private not-profit-making sector. It is difficult to motivate private- for-profit institutions to answer a questionnaire and provide information. Most often, they do not exchange samples and in that case are not in the scope of this study. The number of institutions we surveyed is similar to that in a study of DNA diagnostic laboratories in the USA and Canada. ${ }^{2}$ National, large-scale population biobanks were avoided as they have been comprehensively dealt with elsewhere ${ }^{16,34}$ and have not been in existence for a sufficiently long period. In addition, the development of their activities has been accompanied by specific national legislation. ${ }^{35,56}$ Such large banks are recent rather than long-standing and our purpose was to concentrate on existing well-established situations. The emerging picture is that common characteristics are shared by professional sectors rather than by country, and so the banks surveyed may be considered to provide a reasonably complete picture of well-established biobanking activity in Europe.

\section{Types of biobanks}

Many different classifications of biobanks have been proposed based on various criteria. ${ }^{24,35,40,47}$ This survey enabled us to distinguish six main types of human biobanks: small public collections, large public collections, databases only, private collections, private not-for-profit sector collections and specialised collections (for instance, forensic institutes, blood banks and centres for the study and preservation of sperm). The specialisation of the institution, size and context of the collections were the most discriminating parameters. We were not able to assess the proportion of such biobanks in each country.

\section{Common trends across countries}

In spite of the diversity of the institutions studied in the various countries, common trends emerge. Public research and/or healthcare institutions have a key role in biobanking activity. Biobanking is increasing in all countries because few samples are discarded and because activities related to genetics are proliferating. Existing collections vary in size, with small collections outnumbering large ones. Specific diseases often motivate their establishment. Their purpose is often research, or research and healthcare. A dedicated budget is very rarely allocated to the biobanking activity itself. Storage costs are consequently not often evaluated, but they are low compared to the cost of actually handling the samples. Samples are usually provided free of charge; gifts and exchanges are the common rule. Shipping costs are those most commonly charged to users. Good practice guidelines are generally followed and quality controls performed, but quality procedures are not always clearly explained. Accreditation is sometimes cited but not documented. Associated data are often computerised; in general, identity information is linked and data are either identified or more often identifiable. The administrative and ethical framework, although variable, translates in practice as written information and consent, which has been generally applied mainly since the 1990s. However, its content is very diverse in terms of details and 
type of information given. Biobankers are generally against centralisation of samples but favourable to centralisation of data. European legal and ethical harmonisation is generally seen in a positive light and could facilitate international collaboration, which is increasingly frequent because of the development of genetic banking; but questions are raised about the feasibility of an ethical framework at EU level.

\section{Biobanking genetic material can be seen as a strategic activity for institutions}

Strategic resources lead to strategic alliances. Hospitals are the central platform for collecting samples and the other actors attempt to obtain samples via strategic alliances or contracts. The latter may be research contracts with public research laboratories, but also clinical trial contracts with pharmaceutical companies where material transfer agreements had been signed. Even if little is known about the scale of collections in large pharmaceutical companies, the various industry reports, stock exchange information and our interviews suggest that the banking of genetic samples is now a routine activity, with large banks and little accessibility to other actors. The strategic importance of biobanking cannot be measured through the budget allocated by the different institutions to this activity. There is nevertheless another indicator: a large majority of bankers perceive their collections as possessing a specificity which renders them particularly original or useful to the institution. Most collections in existence for more than 11 years were considered as original. They were original because first of all, samples were unique, rare or impossible to replicate; in some cases, because of the variety of samples or their quantity or because or their age; in a few cases, because of the highly organised nature of the collection. The type or degree of originality of biological material depends entirely on the state of science at a given moment and is also highly dependent on the quality of the associated data. For example, tumour tissues have long been considered waste or archive material only but can now be a valuable resource for biochemical or genetic analysis, especially if linked with clinical data. ${ }^{6}$

So although samples are a strategic resource, rigorous organisation and protection are lacking. This finding is in agreement with other studies. ${ }^{36,57}$ Although the importance of the collections is evident for those involved, no bank has specific insurance coverage of the samples. No insurance company proposes coverage for biological samples used in genetics.

The strategic importance of samples leads to a lack of openness. Those responsible for collections control the flow of samples and are not very enthusiastic about exchanging their collections. A material transfer agreement rarely exists even if this is usually provided for, in the administrative or legal services of the institution. Exchanges are most often controlled through person-to- person contacts with potential users. Guarantees against secondary use of samples for purposes other than the initial purposes or for commercial ends are only verbal and rely on trust or are mentioned in a letter. A large majority of biobankers cited a simple letter of agreement, only one or two in each country alluded to material transfer agreements, and two used cooperation contracts. The written contract is more often required when pharmaceutical companies participate. On the other hand, exchanges are closely controlled and restricted when samples are preserved because of a legal obligation (forensic institutions). As actors perceive the strategic aspects of biobanking, they rarely communicate the nature of samples stored in their institution and are often unaware whether other banks have samples on the same pathology, leading to unwitting duplication. Little or no information circulates outside the bank, although indirect or partial reports may be available via publications, web sites or databases. Some biobankers were willing to disseminate information but deplored the lack of an official and explicit medium.

Distinct dissociation between private for-profit and public or private not-profit-making flows of samples often creates entry barriers between sectors. The French survey shows that public banks let their access being more open to public users than to private users, whereas private banks do not discriminate between users and are either totally open to any kind of users or totally closed. In the other EU countries, most exchanges involving public institution biobanks also appear to be restricted or to take place preferentially with other public users.

\section{The relation between scarcity of economic} information, flexibility of organisation, strategic control by biobankers rather than by institutions and ethical issues

The apparent paradox of the situation we observed, namely that of a strategic activity about which very little economic information is available, is rooted in a long-standing activity that was poorly regulated. Until recently, it was perceived to be of importance only at a small-scale professional level (medical or scientific, within disciplines) and on the basis of short-term use, given the techniques existing at the time of population sampling. The parallel technological explosion leading to long-term preservation and use, the new economic importance of collections for networks in genomics and the pharmaceutical industry, the consequent increase in exchanges and the growing awareness of ethical issues in genetics have disrupted this loosely organised sector. Professionals recognise the need for better organisation at all levels if the scale of activity is indeed changing, but are reluctant to submit to more stringent rules when the activity is not changing, as is the case in a number of small banks. The desire for a welldefined budget and clearer rules and frameworks is 
incompatible with a biobanking activity somewhat interwoven with others. More control leads to less flexibility and freedom, especially when a new kind of profession, namely the professional biobankers, make their appearance.

An ambiguous professional position for biobankers The profession of biobanker is neither explicitly defined, nor widely recognised. Only rare sites are really operating as banks with regular in and out exchanges. Although cooperation between numerous researchers in different countries exists, human biobanking activity is not usually organised in networks. It is carried out in small or large centres such as hospital laboratories; the idea of establishing structured networks has been emerging only since 1995-2000. At the moment, when biobankers participate in networks, these are networks of sample collecting rather than networks of banks. The more or less critical nature of resources to which the laboratory would like to have access depends on its position in the network and also on the position of the other laboratories with which it works. ${ }^{58}$ In this respect, the outcome of the mission set up by the OECD on Biological Resource Centres (BRC), of which France has been appointed as co-ordinator, will be particularly interesting. ${ }^{44}$ The French Research Ministry has launched an initiative concerning such centres which covers not only human biobanking but also biological resources from any species. ${ }^{42}$ The birth of this new profession is not to be taken lightly and the challenge is greater than usually believed, because this re-organisation has wide-ranging effects and biobanking appears as a strategic node of communication between several very different sectors and actors.

\section{Recommendations and perspectives}

The following recommendations are based on the studies performed in the EUROGENBANK project and in particular on our empirical survey. We propose that they should be put to the EU Commission. We believe they are also important for the scientific community involved.

Efforts must be made toward official recognition and identification of biobanking activity and relevant professions, as well as financial sustainability. There is a need for education on biobanking and for guidelines on the quality of collections. Administrative procedures should be simplified and harmonised, and uniformity of import/export regulations within the EU is required. Regarding practical organisation, while support at a central level and the development of platforms for exchanges are desirable, the actors involved gave priority to centralisation of data concerning samples (interconnected databases), not of samples themselves. Harmonising the framework for consent forms, secondary use of samples, gene ownership and constructing a European view on benefit sharing are also seen to be important. Models of consent forms and transfer agreements that correspond to the common requirements of European countries but that are adapted to the various professional contexts would be useful tools. Availability of the complementary regulatory requirements of each country, assembled in an easily accessible central resource, would facilitate collaboration, as would the designation of a person or body at EU level responsible for biobanking for contacting on for related questions. Launching detailed cost evaluation and the preparation of a European central database or interconnected databases on biobank content and rules of access are two additional initiatives, which would be of benefit for the construction of the European Research Area along the lines of the present EU Commission policy.

In conclusion, biobanking is a lively and growing activity in Europe, which has been carried on in numerous institutions for a considerable time. Its rather loose organisation, when on a small scale, is not adapted to forthcoming large-scale projects. One of the issues to be faced in setting standards ${ }^{59}$ is to work out how, on the one hand, the new applications can best be organised in respect of ethical principles ${ }^{60,61}$ without preventing, on the other hand, the continuation and use of the large variety of biobanks that have proven their value over many years. Empirical studies such as the present survey, together with wide-ranging exchange of views at European level and multidisciplinary approaches, are useful tools in this challenging field.

\section{Acknowledgements}

The authors thank the EU Commission for financial support (BIOTECH EU Contract N。BIO4-CT98-0570) and local collaborators who have helped collecting and analysing data. They gratefully acknowledge all the institutions concerned with biobanking of human samples and genetic data, which agreed to be interviewed and to devote time to answering questionnaires. This work was also supported by Genopole-Toulouse Midi-pyrénées.

\section{References}

1 Steinberg KK, Sanderlin KC, Ou CY, Hannon WH, McQuillan GM, Sampson EJ: DNA banking in epidemiologic studies. Epidemiol Rev 1997; 19: 156-162.

2 McEwen JE, Reilly PR: A survey of DNA diagnostic laboratories regarding DNA banking. Am J Hum Genet 1995; 56: 1477-1486.

3 McEwen JE: Forensic DNA data banking by state crime laboratories. Am J Hum Genet 1995; 56: 1487-1492.

4 Narod S, Rosenblatt D, Lamothe E: The banking of DNA for the prevention of genetic disease. Clin Invest Med 1991; 14: 359-362.

5 Sherman JK: Synopsis of the use of frozen human semen since 1964: state of the art of human semen banking. Fertil Steril 1973; 24: 397-412.

6 Becich MJ: The role of the pathologist as tissue refiner and data miner: the impact of functional genomics on the modern pathology laboratory and the critical roles of pathology informatics and bioinformatics. Mol Diagn 2000; 5: 287-299.

7 Baird PA: Identifying people's genes: ethical aspects of DNA sampling in populations. Perspect Biol Med 1995; 38: 159-166. 
8 Nordestgaard BG, Agerholm-Larsen B, Wittrup HH, TybjaergHansen A: A prospective cardiovascular population study used in genetic epidemiology. The Copenhagen City Heart Study. Scand J Clin Lab Invest Suppl 1996; 226: 65-71.

9 Pero RW, Olsson A, Bryngelsson C et al: Feasibility and quality of biological banking of human normal and tumor tissue specimens as sources of DNA for the Malmo Diet and Cancer Study. Cancer Epidemiol Biomarkers Prev 1998; 7: 809-812.

10 Ellsworth DL, Manolio TA: The emerging importance of genetics in epidemiologic research. I. Basic concepts in human genetics and laboratory technology. Ann Epidemiol 1999; 9: $1-16$.

11 Omenn GS: Public health genetics: an emerging interdisciplinary field for the post-genomic era. Annu Rev Public Health 2000; 21: $1-13$.

12 Issa AM: Ethical considerations in clinical pharmacogenomics research. Trends Pharmacol Sci 2000; 21: 247-249.

13 Hagmann M: Epidemiology. U.K. plans major medical DNA database. Science 2000; 287: 1184.

14 Chadwick R: The Icelandic database - do modern times need modern sagas? BMJ 1999; 319: 441-444.

15 Frank L: Population genetics. Estonia prepares for national DNA database. Science 2000; 290: 31.

16 Kaye J, Martin P: Safeguards for research using large scale DNA collections. BMJ 2000; 321: 1146-1149.

17 Pero RW, Olsson A, Bryngelsson C et al: Quality control program for storage of biologically banked blood specimens in the Malmo Diet and Cancer Study. Cancer Epidemiol Biomarkers Prev 1998; 7: 803-808.

18 Yates JR, Malcolm S, Read AP: Guidelines for DNA banking. Report of the Clinical Genetics Society working party on DNA banking. J Med Genet 1989; 26: 245-250.

19 DNA banking and DNA analysis: points to consider. Ad Hoc Committee on DNA Technology, American Society of Human Genetics. Am J Hum Genet 1988; 42: 781-783.

20 Madisen L, Hoar DI, Holroyd CD, Crisp M, Hodes ME: DNA banking: the effects of storage of blood and isolated DNA on the integrity of DNA. Am J Med Genet 1987; 27: 379-390.

21 HGDP. Model ethical protocol for collecting DNA samples. Stanford USA: Human Genome Diversity Project-Morrison Institute; 1999. http://www.stanford.edu/group/morrison/hgdp/ protocol.html.

22 Knoppers BM, Laberge C: DNA sampling and informed consent. CMAJ 1989; 140: 1023-1028.

23 Reilly PR: DNA banking. Am J Hum Genet 1992; 51: 1169-1170.

24 NBAC. The use of human biological materials in research National Bioethics Advisory Commission USA, 1999. http:// bioethics.gov/briefings/index.htm\#jan99.

25 Knoppers BM, Hirtle M, Lormeau S: Ethical issues in international collaborative research on the human genome: the HGP and the HGDP. Genomics 1996; 34: 272-282.

26 CCNE. Avis no 60. Réexamen des lois de Bioéthique: problèmes éthiques posés par la constitution et l'utilisation de collections d'échantillons biologiques en génétique humaine. 1998. France. http://www.ccne-ethique.org/start.htm. 1998.

27 Knoppers BM (ed). Human DNA: law and policy: international and comparative perspectives. Proceedings of the First International Conference on DNA Sampling and Human Genetic Research: Ethical, Legal, and Policy Aspects, Montreal, Canada, 6-8 September 1996. Boston: Kluwer Law International, 1997.

28 Bondy M, Mastromarino C: Ethical issues of genetic testing and their implications in epidemiologic studies. Ann Epidemiol 1997; 7: 363-366.

29 Moutel G, de Montgolfier S, Corviole K et al: Gestion des biothèques: analyse des enjeux éthiques. Presse Med 1999; 28: 135-139.

30 Cambon-Thomsen A: Les problèmes pratiques et éthiques que pose le stockage des échantillons biologiques . in: Dossier: Médecine prédictive: mythe et réalité; Actualité et dossier en santé publique. Revue du Haut Comité de la Santé Publique, 2001, pp. 55-61.

31 HUGO Ethics Committee. Statement on DNA sampling control and access. http://www.gene.ucl.ac.uk/hugo/sampling.html. Genome Digest 1999; 6: 8-9.

32 Lavori PW, Krause-Steinrauf H, Brophy $\mathrm{M}$ et al: Principles, organization, and operation of a DNA bank for clinical trials: a Department of Veterans Affairs cooperative study. Control Clin Trials 2002; 23: 222-239.

33 Steinberg K, Beck J, Nickerson D et al: DNA banking for epidemiologic studies: a review of current practices. Epidemiology 2002; 13: 246-254.

34 Blatt RJ: Banking biological collections: data warehousing, data mining, and data dilemmas in genomics and global health policy. Community Genet 2000; 3: 204-211.

35 ESHG. Data storage and DNA banking for biomedical research informed consent, confidentiality, quality issues, ownership, return of benefits. A professional perspective. Background document and recommendations of the Eur Soc Hum Genet. 2000. http://www.eshg.org/Banking\%20background\%20consult. pdf.

36 de Montgolfier S, Moutel G, Herve C: Gestion des biothèques. Analyse des pratiques au sein de 20 services hospitaliers. Presse Med 2000; 29: 1752-1758.

37 Hall J, Hamerton J, Hoar D et al. Policy statement concerning DNA banking and molecular genetic diagnosis. Canadian College of Medical Geneticists. Clin Invest Med 1991; 14: 363-365.

38 Commission of the European Communities. Proposal for a Directive of the European Parliament and of the Council on setting standards of quality and safety for the donation, procurement, testing, processing, storage and distribution of human tissues and cells. Journal Officiel des Communautés Européennes 24-09-2002, 2002; $\operatorname{Com}(2002) 319$ final-2002/ 0128(COD), pp. 505-521.

39 Hirtzlin I, Préaubert N, Charru A: Analyse de l'activité et du coût des collections de matériel biologique. J Econom Méd 1999; 17: 311.

40 Cambon-Thomsen A, Rial-Sebbag E: Banques d'échantillons biologiques: aspects éthiques. Rev Epidémiol Santé Publique 2003; 51: 101-110.

41 Persidis A. The business of pharmacogenomics. Nat Biotechnol 1998; 16: 209-210.

42 CCRB. Installation du comité consultatif des ressources biologiques. Speech by M Roger-Gérard Schwartzenberg, ministre de la Recherche, Paris, 22 February 2001, http:// www.recherche.gouv.fr/discours/2001/ccrbiod.htm.

43 Dufourcq E, Lalande F, Delahaye-Guillochau V, Ollivier M: Conservation d'éléments du corps humain en milieu hospitalier. Inspection générale des affaires sociales, Rapport 2002-009. Paris: La Documentation française, 2002.

44 OECD. Biological Resource Centres: Underpinning the Future of Life. Sciences and Biotechnology; OECD Code 932001041E1. 2001. http://oecdpublications.gfi-nb.com/cgi-bin/OECDBookShop. storefront/EN/product/932001041E1.

45 Arrow K: Gifts and exchanges. Philos Public Affairs 1972; 1: 343 362.

46 Rial-Sebbag E: Aspects juridiques des banques d'échantillons biologiques en France. Rev Epidemiol Santé Publique 2003; 51: 111 120.

47 Cambon-Thomsen A, Rial-Sebbag E, Duchier J: Aspects éthiques et réglementaires des collections d'échantillons biologiques: synthèse, questions pratiques et propositions. Rev d'Epidemiol et Santé Publique 2003; 51: 121-126.

48 Dubreuil C, Duchier J, Cambon-Thomsen A: Médecins, chercheurs et patients face aux banques d'échantillons biologiques humains. Rev Praticien 2001; 51: 469-472.

49 HUGO Ethics Committee. Statement on benefit sharing. 2000. http://www.hugo-international.org/hugo/benefit.html.

50 ASHG. Statement on informed consent for genetic research. Am J Hum Genet 1996; 59: 471-474. 
51 Deschenes M, Cardinal G, Knoppers BM, Glass KC: Human genetic research, DNA banking and consent: a question of 'form'? Clin Genet 2001; 59: 221-239.

52 Weir RF, Horton JR: DNA banking and informed consent - part 1. IRB 1995; 17: 1-4

53 Weir RF, Horton JR: DNA banking and informed consent - part 2. IRB 1995; 17: 1-8.

54 Sass HM: Genotyping in clinical trials: towards a principle of informed request. J Med Philos 1998; 23: 288-296.

55 Gros F (ed). Les sciences du vivant. Ethique et société. Paris: ed Odile Jacob, 2001.

56 deCode. http://www.decode.com/news/releases/item.ehtm?id= 17881 A joint statement from deCODE Genetics and the Icelandic Medical Association http://brunnur.stir.is/interpro/htr/ htr.nsf/pages/gagngr-log-ensk Act on a Health Sector Database no. 139/1998. 2001
57 Moutel G, de Montgolfier S, Meningaud JP, Herve C: Bio-libraries and DNA storage: assessment of patient perception of information. Med Law 2001; 20: 193-204.

58 Joly PB, Mangematin V: Strategic games of appropriation during scientific production: the example of molecular biology. Paper presented at the Conference New Economics of Science, Notre Dame, USA, 13-16 March, 1997.

59 McEwen JE, Reilly PR: Setting standards for DNA banks: toward a model code of conduct. Microbiol Comp Genomics 1996; 1: 165177.

60 Kaye J: Genetic research on the UK population - do new principles need to be developed? Trends Mol Med 2001; 7: 528530.

61 Chadwick R, Berg K: Solidarity and equity: new ethical frameworks for genetic databases. Nat Rev Genet 2001; 2: 318-321. 